\title{
The Effects of Growth Substances on Intercalary Growth and Cellular Differentiation in Developing Internodes of Avena sativa
}

\author{
II. The Effects of Gibberellic Acid
}

By

Peter B. Kaufman

Department of Botany, University of Michigan, Ann Arbor, Michigan and Institute of Plant Physiology, Lund University, Lund, Sweden

(Received March 25, 1965)

\section{Introduction}

A substantial number of papers on the effects of gibberellic acid on cell division and cell elongation have appeared in the last several years (Allsopp 1962, Bernier et al. 1964, Bradley and Crane 1962, Burström 1960, Greulach and Haesloop 1958, Guttridge and Thompson 1963, Humphries and Wheeunler 1960, Kato 1955, Odhnoff 1963, Sachs et al. $1959 a, b)$. Most of these investigations have been concerned with changes in patterns of cell division and cell elongation in stems, leaves, roots, and sporelings in connection with mature tissue systems or primary meristematic tissues subjacent to root or shoot apices.

As far as the writer is aware, no detailed analysis has been made on the effect of gibberellins on cell division, cell enlargement, or cellular differentiation in a detached meristem such as the intercalary meristem of grass internodes. They only analogous studies are those pertaining to the effects of gibberellic acid on cell division and cell enlargement in shoot apices and subjacent axis tissue of certain annuals and biennials (Bernier et al. 1964, Sachs et al. $1959 a, b)$. Thus, the present investigations were undertaken (1) to assess the effects of gibberellic acid on rate and duration of longitudinal growth and on distribution of growth in Avena internodes cultured in light and dark and (2) to determine the effects of gibberellic acid on rates and duration of cell division and cell enlargement and on kinds of cellular differentiation in the intercalary meristem of developing Avena internodes. The primary objective of these studies with gibberellic acid, and those pre- 
viously with indole-3-acetic acid (Kaufman 1965), is to shed more light on possible mechanisms of growth and cellular differentiation in developing internodes of the Avena plant.

\section{Material and Methods}

The subject of these studies was the next to the last internode of the Avena shoot referred to as Avena internode(s) in the text. A diagram of position of this internode in the Avena shoot is depicted in Figure 1 in Kaufman (1965). That portion of the internode of major interest in these investigations was the intercalary meristem. Details on rates and duration of cell division and cell elongation and on pathways of cellular differentiation during intercalary growth in internodes of intact, untreated Avena shoots have been presented previously (Kaufman et al. 1965). They serve as a basis of comparison with the effects of IAA, and here, with gibberellic acid on these growth processes in Avena internodes.

Essentially the same methods as described in the first paper on IAA (Kaufman 1965) were employed in the experiments with gibberellic acid to be reported here. $\mathrm{GA}_{3}$ was used in concentrations varying from $10^{-1}$ to $10^{2} \mathrm{mg} / \mathrm{l}$. $\mathrm{GA}_{3}$, like IAA, was used in the presence of $0.1 M$ fructose for reasons cited in Kaufman et al. (1962). For the sake of clarity, $+G A_{3}$ and $-G A_{3}$ will refer in this paper to treatments that included $0.1 M$ fructose + gibberellic acid and $0.1 M$ fructose alone, respectively. Excised Avena shoot portions were used in most of the experiments cited here, as in the IAA investigations.

One new procedure was employed in the present studies (section 1, Results) to determine more directly the effect of $\pm G A_{3}$ on intercalary meristem activity in internodes of Avena. It is described as follows: Internodes 1.2 to $2.0 \mathrm{~cm}$ in length at time zero were selected from Avena plants growing on a $12 \mathrm{hr}$ light, $12 \mathrm{hr}$ dark cycle at $21^{\circ} \mathrm{C}$ in a growth room. This stage of development of internodes was selected, for it is here that the greatest differential in growth occurs in internodes incubated in the light compared with dark (Figure 2). One $\mathrm{cm}$ internodal segments, together with surrounding sheath portions, were excised with a razor blade guillotine device from the extreme bases of these internodes, excluding the basal node, and including essentially all of the intercalary meristem. These will be referred to as intercalary meristem segments. The sheath portion does not elongate in these segments and offers support for the enclosed internode portion (Figure $1 a$ ). Excised intercalary meristem segments were immediately placed in perforated Plexiglas holders in plastic Petri dishes (Figure $1 \mathrm{~b}$ ) with morphological bases of each in contact with two filter paper dises saturated with $3 \mathrm{ml} 0.1 M$ fructose plus a standard nutrient solution (modified from Burström 1960). The nutrient solution was composed of $\mathrm{K}_{2} \mathrm{HPO}_{4}\left(10^{-3} M\right), \mathrm{Na}_{2} \mathrm{HPO}_{4}\left(10^{-3} M\right)$, Ca $\left(\mathrm{NO}_{3}\right)_{2} \cdot 4 \mathrm{H}_{2} \mathrm{O},\left(10^{-3} M\right), \mathrm{MgSO}_{4}$. - $7 \mathrm{H}_{2} \mathrm{O}\left(2 \times 10^{-3} M\right)$, Fe Versenate $\left(10^{-5} M\right), \mathrm{MnSO}_{4}\left(10^{-6} M\right)$, and $\mathrm{H}_{3} \mathrm{BO}_{3}\left(10^{-6} M\right)$. Following this, a $2.5 \times 2.5 \times 1.0 \mathrm{~mm}$ agar block $\pm G A_{3}$ was placed on the apical end

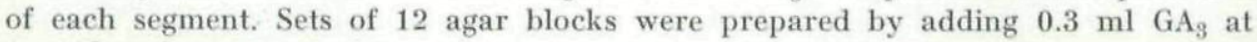
$2 \times 10^{2} \mathrm{mg} / \mathrm{I}$ to $0.3 \mathrm{ml}$ of 3 per cent agar, giving a final gibberellic acid concentration of $10^{2} \mathrm{mg} / \mathrm{l}$. Blocks without $\mathrm{GA}_{3}$ contained 1.5 per cent agar. Twenty intercalary meristem segments were used for each treatment. The plastic Petri dish with its isolated intercalary meristem segments was then placed in a larger plastic dish (Figure $1 \mathrm{c}$ ) filled with water to a depth of $10 \mathrm{~mm}$. This in turn was covered with lid of a large 

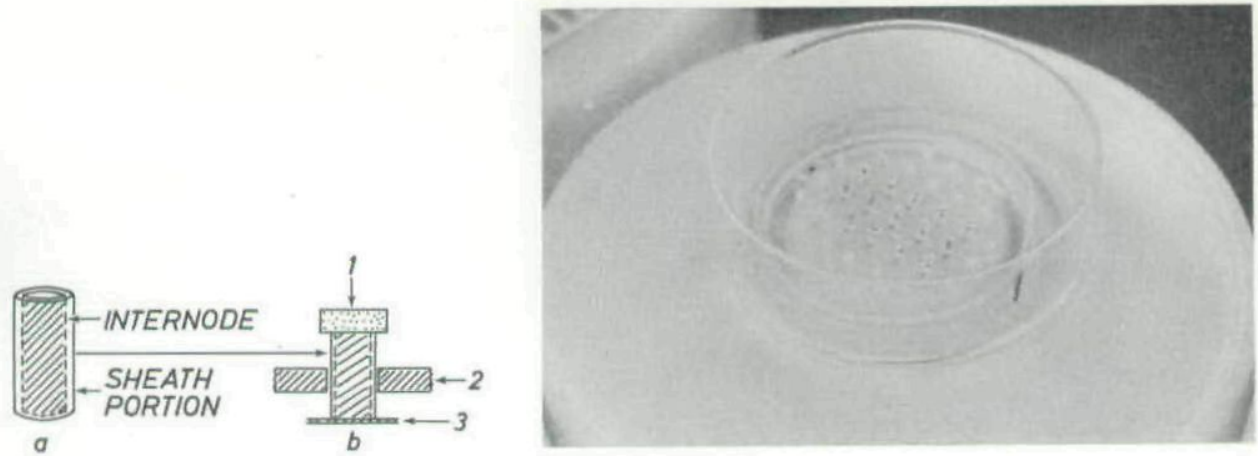

Figure 1. Illustrations depicting procedures for testing the effect of $\pm G A_{3}$ in agar blocks directly on intercalary growth in isolated internodal segments derived from next to last internodes of Avena shoots. $a$, Excised intercalary meristem segment, $1 \mathrm{~cm}$ long; $b$, Intercalary meristem segment supported in plexiglas holder (2) and with agar block (1) applied to the apical surface; (3) filter paper with sugar + nutrient solution; $c$, dish containing plexiglas holder with several intercalary meristem segments supplied with agar blocks.

Petri dish to provide high humidity. This system was not tight enough to prevent air exchange under the lid. Segments were incubated in continuous light or dark. Dishes were illuminated by placing two G.E. Power Groove fluorescent lamps on each side of the dishes, providing a light intensity of 3000 lux at the site of the segments and a temperature of $23^{\circ} \mathrm{C}$. Lengths of internode in intercalary segments were measured every $24 \mathrm{hr}$ up to $72 \mathrm{hr}$. Lengths of dark-incubated segments were measured under a green fluorescent lamp covered with one sheet each of green and amber "Cellon" plastic film.

\section{Results}

\section{The Effect of $\mathrm{GA}_{3}$ on Growth of Avena Internodes and Intercalary Meristem Segments in Light and Dark}

The first problem posed in these investigations was to determine the effect of exogenous gibberellic acid on longitudinal growth of Avena internodes at different stages of development in the light and dark. Stages were selected to include the entire period during which intercalary growth takes place in the internode. Data on net changes in length of internodes, varying in length from 0.15 to $11.0 \mathrm{~cm}$ at time zero, in excised Avena shoots after incubation in solutions of $\pm G A_{3}$ at $10^{2} \mathrm{mg} / \mathrm{l}$ for $96 \mathrm{hr}$ in continuous light or dark are presented in Figure 2. They reveal the following: First, the expected wide differential in net longitudinal growth of internodes in light and dark occurs at a stage when the internode is between 0 and $3 \mathrm{~cm}$ in length. Here, the internode in dark shows a maximum net growth of $3.5 \mathrm{~cm}$ (internode= $1.67 \mathrm{~cm}$ length), whereas in the light, the maximum net extension is only $0.35 \mathrm{~cm}$ (internode $=1 \mathrm{~cm}$ length). Second, the amount of promotion of longitudinal growth by $+G A_{3}$ in dark increases between 0 and $1 \mathrm{~cm}$ length of the internode, and in light, between 0 and $1.5 \mathrm{~cm}$ length of the internode. 


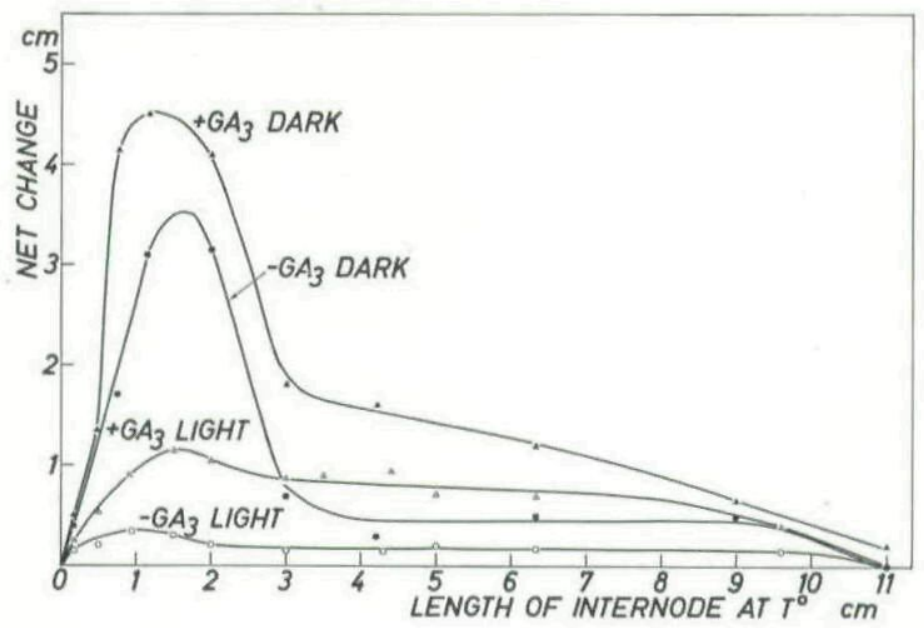

Figure 2. Net changes in length of internodes at different stages of development in excised Avena shoots incubated in $\pm G A_{3}$ at $10^{2} \mathrm{mg} / \mathrm{l}$ in light and dark for $96 \mathrm{hr}$ at $22.5^{\circ} \mathrm{C}$. Length of internode at time zero varied from 0.15 to $11.0 \mathrm{~cm}$. Light $=18 \mathrm{hr}$ light at $2000 \mathrm{lux}, 6 \mathrm{hr}$ dark in 24 hr cycles. Dark = continuous darkness.

It is fairly constant in both light and dark for internodes between 2 and $6 \mathrm{~cm}$. The growth promoting effect of gibberellic acid then decreases rather substantially for older internodes, i.e., $>6 \mathrm{~cm}$ in length. Third, gibberellic acid fails to overcome completely the light-induced suppression of longitudinal growth in the internode for early stages in its development $(0$ to $3 \mathrm{~cm}$ length). The maximum increase in length of the internode elicited by $+G A_{3}$ in the light is only $0.85 \mathrm{~cm}$ (internode $=1.7 \mathrm{~cm}$ length), leaving a deficit of $2.35 \mathrm{~cm}$ from the dark level of growth. Only at later stages of development (internodes 3 to $11 \mathrm{~cm}$ length) does $+G A_{3}$ increase longitudinal growth to levels which exceed those in $-G A_{3}$, dark-incubated shoots. It is obvious from this stage experiment that gibberellic acid has a promotion effect on longitudinal growth of internodes in both light and dark. In the dark, it accentuates the peak in growth that occurs during early stages of development of the internode. In the light, it increases net longitudinal growth for almost all stages of development of the internode.

Figure 3 shows the time-course growth responses of one series of internodes, initially $2.6 \mathrm{~cm}$ in length, to $\pm G A_{3}$ at $10^{2} \mathrm{mg} / \mathrm{l}$ in light and dark. The data are derived from an experiment in which net increase in length of internodes in $\pm G A_{3}$ in light and dark was slightly greater than at the comparable stage in Figure 2. The relative differences in growth, however, are essentially the same. The curves reveal that $+G A_{3}$ accelerates longitudinal extension in the internode in both light and dark. The acceleration persists for ca. $20 \mathrm{hr}$. Duration of longitudinal growth in internodes, which is shorter in light than in dark, is not markedly altered by $+G A_{3}$ treatment. One further point is the pronounced lag phase in longitudinal growth during the 0 to $20 \mathrm{hr}$ period in $-G A_{3}$, dark-incubated internodes, when during this same 
Figure 3. Time-course growth responses in internodes (initially $2.6 \mathrm{~cm}$ in length) in excised Avena shoots to $\pm G A_{3}$ at $10^{2} \mathrm{mg} / \mathrm{l}$ in light and dark at $22.5^{\circ} \mathrm{C}$.

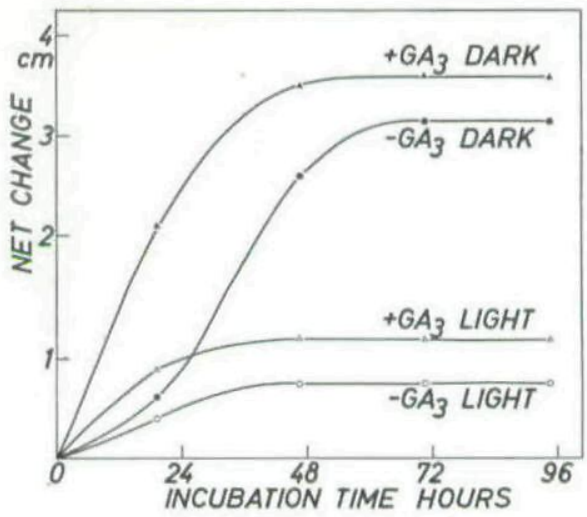

period, $+G A_{3}$ accelerates the growth rate of the internode. Only after $20 \mathrm{hr}$ do growth rates for $+G A_{3}$ and $-G A_{3}$, dark-incubated internodes become the same. The time-course growth responses illustrated in Figure 3 are also similar for internodes at younger and slightly older stages of development, i.e., from 0.5 to $3 \mathrm{~cm}$ length at time zero. The salient point here is that $+G A_{3}$ promotes longitudinal growth in the internode in both light and dark, as so clearly shown in Figures 2 and 3 , such that $+G A_{3}$ internodes and $-G A_{3}$ internodes appear to be two physiologically different growth systems.

One may next ask: What is the effect of gibberellic acid on extension of isolated portions of the internode that include only the intercalary meristem? Thus, one $\mathrm{cm}$ intercalary meristem segments were excised from basal portions of internodes, initially $1.3 \pm 0.3 \mathrm{~cm}$ in length, according to procedures cited in methods and illustrated in Figure 1. Growth responses of these segments to $+G A_{3}$ at $10^{2} \mathrm{mg} / \mathrm{l}$ in light and dark during a $75 \mathrm{hr}$ incubation period are depicted in Figure 4. The following points are evident: (1) $+G A_{3}$ strongly

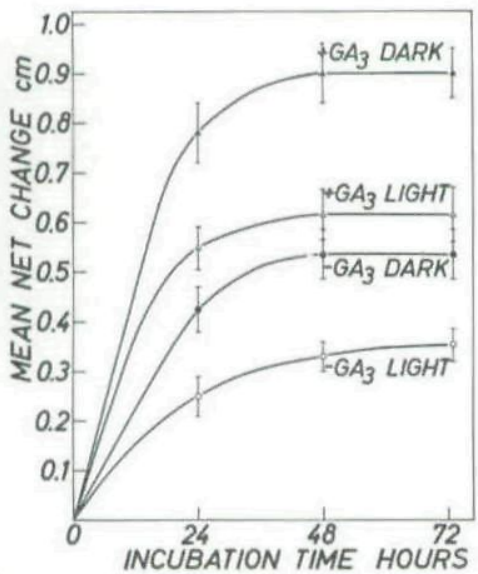

Figure 4. Growth responses of excised intercalary meristem segments to $\pm G A_{3}$ at $10^{2} \mathrm{mg} / \mathrm{l}$ in continuous light and dark during a 75 hr incubation period at $22.5^{\circ} \mathrm{C}$. Segments were obtained from internodes $1.3 \pm 0.3 \mathrm{~cm}$ in length at time zero and were $1 \mathrm{~cm}$ in length. 
accelerates the growth rate of intercalary meristem segments in both light and dark during the first $24 \mathrm{hr}$ of incubation; (2) the rate of growth of intercalary meristem segments in $+G A_{3}$ is slower in light than in dark; $(3)$ the duration of growth in $-G A_{3}$ segments is ca. $48 \mathrm{hr}$, which is not significantly different from that in $+G A_{3}$ segments; (4) the amount of promotion of growth at $75 \mathrm{hr}$ by $+G A_{3}$ in dark-incubated segments is ca. 1.5 times as great as that of $+G A_{3}$, light-incubated segments. If one compares the growth responses of intercalary meristem segments (Figure 4) with those of internodes in excised shoots (Figure 2), it is quite apparent that there is no marked differential at $75 \mathrm{hr}$ between net growth of light and dark-incubated $-G A_{3}$ segments, in contrast with the occurrence of a striking differential for $-G A_{3}$ treated internodes in excised shoots (internode $=1.3 \mathrm{~cm}$ length) incubated in light and dark. The light level of growth is essentially the same in both systems, i.e., ca. $0.35 \mathrm{~cm}$ net growth. In the dark, however, net growth of intercalary meristem segments is only $0.53 \mathrm{~cm}$, whereas it is about $3.35 \mathrm{~cm}$ in the internodes. Thus, with intercalary meristem segments, the growth elicited by $+G A_{3}$ in the light is essentially the same as for $-G A_{3}$ in the dark. For the same stage of development of the internode in excised shoots, the growth of $-G A_{3}$, dark-incubated internodes greatly exceeds that of $+G A_{3}$, light-incubated internodes. Nevertheless, in intercalary meristem segments, as in internodes, $+\mathrm{GA}_{3}$ promotes longitudinal growth in both light and dark, underlining the point that $+G A_{3}$ and $-G A_{3}$ internodes or segments appear to be physiologically different and independent growth systems.

\section{The Effects of Gibberellic Acid at Several Concentrations on Growth of Avena Internodes in Excised Shoots}

$\mathrm{GA}_{3}$ in these experiments was used at concentrations of $10^{-1}, 1,10$, and $10^{2} \mathrm{mg} / \mathrm{l}$. A stage of development of the internode $(1.22 \mathrm{~cm}$ length) was selected where a wide differential in growth response to $+G A_{3}$ and $-G A_{3}$ occurs in the dark (Figure 2). The experiments were repeated three times. Excised Avena shoots were incubated in the dark for $120 \mathrm{hr}$. Curves in Figure 5 reveal that $\mathrm{GA}_{3}$ under these conditions promotes longitudinal growth of internodes in these shoots over the entire concentration range of $\mathrm{GA}_{3}$ that was employed. Maximum promotion occurred at $10^{2} \mathrm{mg} / \mathrm{l}$, the least at $10^{-1}$ $\mathrm{mg} / \mathrm{l}$. The curves in Figure 5 also show that the acceleratory effect of gibberellic acid is evident during the first $24 \mathrm{hr}$ of incubation, continues for ca. $72 \mathrm{hr}$, then diminishes to zero between 72 and $120 \mathrm{hr}$. The duration of lonigtudinal growth was not significantly altered by $+G A_{3}$ at any of these concentrations.

The growth rates of internodes in excised Avena shoots incubated in $+G A_{3}$ medium are equal to or greater than those which occur in intact Avena internodes. For example, in intact Avena shoots with the internode $1.25 \mathrm{~cm}$ in length, the growth rate of the internode is ca. $0.4 \mathrm{~cm} / 24 \mathrm{hr}$. Maximum rates of linear extension occur when internodes are about $4 \mathrm{~cm}$ in length, i.e., ca. $2.1 \mathrm{~cm} / 24 \mathrm{hr}$ (Kaufman et al. 1965). In the experiments cited here with excised shoots (Figure 5), the maximum rate of growth approaches $1.5 \mathrm{~cm} / 24 \mathrm{hr}$ at $10^{2} \mathrm{mg} / 1 \mathrm{GA}_{3}$ and $0.4 \mathrm{~cm} / 24 \mathrm{hr}$ at $10^{-1} \mathrm{mg} / \mathrm{l} \mathrm{GA}$. Thus, the internode has the potential before it enters the period of its maximum rate 
Figure 5. Growth curves for internodes in excised Avena shoots incubated in GA3 varying from $10^{-1}$ to $10^{2} \mathrm{mg} / \mathrm{l}$. Shoots were incubated in continuous darkness for $120 \mathrm{hr}$ at $22.5^{\circ} \mathrm{C}$. Mean length of internode at time zero was $1.22 \pm 0,20 \mathrm{~cm}$. Points represent mean values for 20 internodes. Max. standard error was $\pm 0.31 \mathrm{~cm}$ for $\mathrm{GA}_{3}$ at $10^{2} \mathrm{mg} / \mathrm{l}$ at $120 \mathrm{hr}$; average standard error was $0.19 \mathrm{~cm}$ at $120 \mathrm{hr}$.

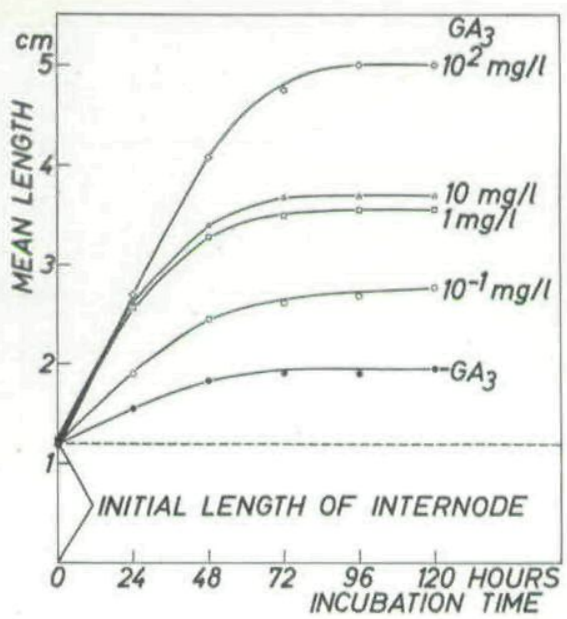

Table 1. Effect of three concentrations of gibberellic acid on maximum diameter, dry weight, and net change in length of internodes in excised Avena shoots after incubation in continuous darkness for $120 \mathrm{hr}$ at $22.5^{\circ} \mathrm{C}$. Mean values for 20 shoots. Initial length of internode was $1.22 \pm 0.20 \mathrm{~cm}$. Maximum standard error of mean internodal diameter was $\pm 0.01 \mathrm{~mm}$. Measurements were made ca $0.5 \mathrm{~cm}$ above base of the internode.

\begin{tabular}{|c|c|c|c|}
\hline Treatment & $\begin{array}{l}\text { Maximum diameter } \\
\mathrm{mm}\end{array}$ & $\begin{array}{l}\text { Mean dry weight } \\
\text { per internode } \\
\text { g }\end{array}$ & $\begin{array}{c}\text { Net change in length } \\
\text { of internode } \\
\mathrm{cm}\end{array}$ \\
\hline $\begin{array}{lllll}G A_{3} & \ldots \ldots \ldots \ldots \ldots \\
+G A_{3} & 1 & 1 \mathrm{mg} / 1 & \ldots & \ldots \\
+G A_{3} & 10 \mathrm{mg} / 1 & \ldots \\
+G A_{3} & 10^{2} \mathrm{mg} / 1 & \ldots\end{array}$ & $\begin{array}{l}1.95 \\
2.03 \\
1.98 \\
2.03\end{array}$ & $\begin{array}{l}5.0 \times 10^{-3} \\
6.4 \times 10^{-3} \\
7.1 \times 10^{-3} \\
8.2 \times 10^{-3}\end{array}$ & $\begin{array}{l}0.23 \\
2.33 \\
2.49 \\
3.56\end{array}$ \\
\hline
\end{tabular}

of growth to attain growth rates in the presence of $\mathrm{GA}_{3}$ which are nearly as great as the maxmium rates which are achieved in internodes in intact Avena shoots.

Gibberellic acid, unlike IAA, does not cause any significant increase in diameter of the internode (Table 1). However, it does cause a substantial increase in internode dry weight. The greatest increase in dry weight occurs at $10^{2} \mathrm{mg} / 1 \mathrm{GA}_{3}$, the least at $10^{-1} \mathrm{mg} / 1$ concentration. This increase in dry weight of the internode elicited by gibberellic acid is probably related to the augmented linear growth in the internode caused by $\mathrm{GA}_{3}$.

\section{The Effect of Gibberellic Acid on Distribution of Growth in Internodes of Excised Avena Shoots}

Using the marking procedures described earlier (Kaufman 1965), an analysis was made to determine the location of the $\mathrm{GA}_{3}$-induced promotion of elongation in Avena internodes. In these experiments, internodes of different 
Table 2. Number of $2 \mathrm{~mm}$ intervals which change in length compared with total number of $2 \mathrm{~mm}$ intervals ${ }^{1}$ in marked Avena internodes after $96 \mathrm{hr}$ incubation in \pm GA at $10^{2} \mathrm{mg} / \mathrm{l}$ in light and dark. Light: $18 \mathrm{hr}$ light, $6 \mathrm{hr}$ dark, $24 \mathrm{hr}$ cycles, $2000 \mathrm{lux}, 22.5^{\circ} \mathrm{C}$. Dark: continuous darkness, $22.5^{\circ} \mathrm{C}$.

\begin{tabular}{|c|c|c|c|c|}
\hline \multirow{2}{*}{$\begin{array}{c}\text { Initial length of } \\
\text { internode } \\
\mathrm{cm}\end{array}$} & \multicolumn{2}{|c|}{ Light } & \multicolumn{2}{|c|}{ Dark } \\
\hline & $-G A_{3}$ & $+G A_{3}$ & $-G A_{3}$ & $+G A_{3}$ \\
\hline 0.25 & $1 / 1$ & $1 / 1$ & $1 / 1$ & $1 / 1$ \\
\hline 0.60 & $2 / 3$ & $2 / 3$ & $2 / 3$ & $2 / 3$ \\
\hline 0.70 & $3 / 3$ & $2 / 3$ & $3 / 3$ & $2 / 3$ \\
\hline 0.80 & $3 / 4$ & $3 / 4$ & $3 / 4$ & $3 / 4$ \\
\hline 1.10 & $4 / 5^{1}$ & $4 / 5$ & $4 / 5$ & $4 / 5$ \\
\hline 1.90 & $4 / 9$ & $5 / 9$ & $5 / 9$ & $4 / 9$ \\
\hline 2.60 & $5 / 13$ & $5 / 13$ & $5 / 13$ & $6 / 13$ \\
\hline 4.00 & $4 / 20$ & $5 / 20$ & $5 / 20$ & $6 / 20$ \\
\hline 5.20 & $3 / 26$ & $5 / 26$ & $5 / 26$ & $6 / 26$ \\
\hline 5.90 & - & $5 / 29$ & $3 / 29$ & $4 / 29$ \\
\hline 7.40 & $3 / 37$ & $6 / 37$ & - & $5 / 37$ \\
\hline
\end{tabular}

1 For example, 4/5 in column 2 means that 4 intervals out of total of 5 intervals on the internode changed in length after $96 \mathrm{hr}$ incubation of excised shoot.

stages of development were employed ( 0.25 to $7.4 \mathrm{~cm}$ length), using continuous light and dark regimes. The following results (Table 2) were obtained: The linear growth response of internodes to $+G A_{3}$ is essentially confined to the basal part of the internode ( 8 to $12 \mathrm{~mm}$ portion) except for internodes $<2 \mathrm{~cm}$ long, where the entire internode is involved. In internodes $>4 \mathrm{~cm}$ long, $+G A_{3}$ promotes longitudinal growth in one or two more intervals than in $-G A_{3}$ internodes incubated in light or dark.

Changes in length of particular on marked internodes, initially $1.1 \mathrm{~cm}$ in length, incubated in $\pm \mathrm{GA}_{3}$ in light and dark, are depicted in Figure 6 . The two basal-most intervals $(4 \mathrm{~mm}$ portion at extreme base of the internodes) show the greatest change in length and intervals 3 and 4 a lesser amount of extension in $-G A_{3}$, dark-incubated shoots. $+G A_{3}$ causes a striking increase in growth in intervals 1 and 2, a lesser increase in interval 3 . These are the same intervals primarily involved in intercalary growth response in $-G A_{3}$, dark-incubated shoots. In older internodes, the growth response to gibberellic acid is confined more to the base of the internode. This analysis thus shows that $+G A_{3}$ in light or dark has the effect of greatly augmenting the amount of growth which takes place in the intercalary meristem locus during early stages of development of the internode.

A time-course plot of the growth responses in intervals 1 and 2 at the extreme basal $4 \mathrm{~mm}$ portion of the above internode revealed that the growth acceleration effect of $\mathrm{GA}_{3}$ takes place during the first $36 \mathrm{hr}$ of growth with maximum rates of acceleration occurring between 24 and $36 \mathrm{hr}$ after time zero. By the end of $48 \mathrm{hr}, \mathrm{GA}_{3}$ only has a small effect on growth in the intercalary meristem locus of these internodes. It is clear from these observations that the acceleratory effect of gibberellic acid on interealary growth in Avena internodes at this stage of development in excised shoots is fairly rapid, localized, and of short duration. 


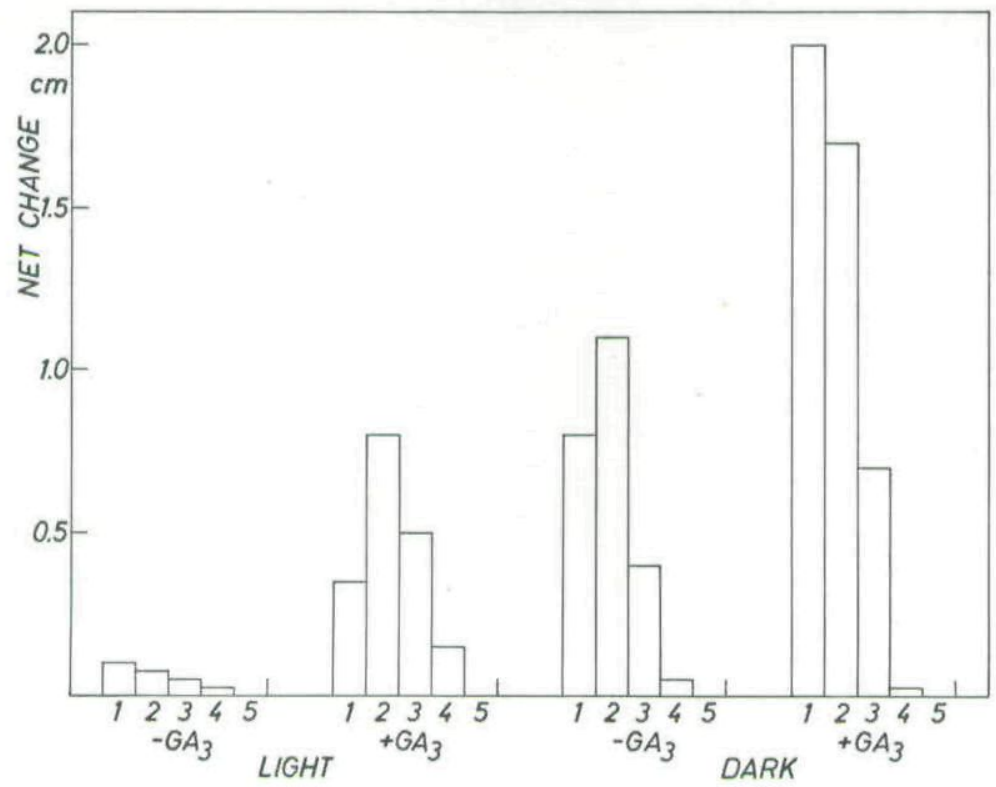

Figure 6. Net changes in length of five $2 \mathrm{~mm}$ intervals on marked internodes in excised Avena shoots incubated in $\pm G A_{3}$ at $10^{2} \mathrm{mg} / \mathrm{l}$ in light and dark for $94 \mathrm{hr}$ at $22.5^{\circ} \mathrm{C}$. Interval no. 1 is at extreme base of internode, no. 2 directly above no. 1 , etc. Initial length of internode $=1.1 \mathrm{~cm}$. Final lengths were $1.5 \mathrm{~cm}\left(-G A_{3}\right.$, light $), 2.9 \mathrm{~cm}\left(+G A_{3}\right.$, light $), 3.2 \mathrm{~cm}$ $\left(-G A_{3}\right.$, dark $), 5.5 \mathrm{~cm}\left(+G A_{3}\right.$, dark $)$.

\section{Cytological Basis for Changes in Intercalary Growth Patterns} Elicited by Gibberellic Acid in Avena Internodes

One of the primary questions posed by results in the preceding sections is whether promotion in linear growth rate of internodes in excised Avena shoots by gibberellic acid is due to changes in rate or duration of cell division, cell enlargement, or both processes. Further, does $\mathrm{GA}_{3}$ cause any significant alterations in patterns of cellular differentiation in the epidermal system within and above the intercalary meristem locus of Avena internodes?

a. Effect of $G A_{3}$ on cell division. - Avena shoots with internodes at several stages of development were incubated in $\pm G A_{3}$ at $10^{2} \mathrm{mg} / 1$ in light and dark for periods up to $72 \mathrm{hr}$. Epidermal peels were taken at $24 \mathrm{hr}$ intervals at the site of the intercalary meristem and in apical and middle positions. They were stained with acetocarmine as described in Kaufman and Cassell (1963). From these same internodes, fresh longisections, representing the entire length of the internode, were stained in acetocarmine and used for measurement of cell size and cell number in continuous files of pith cells extending from top to base of the internode.

Data on numbers of pith and epidermal cells in continuous cell files (Table 3) reveal that gibberellic acid causes no significant increase in cell 
Table 3. Number of epidermal and pith cells in continuous cell files in \pm GAs-treated $\left(10^{2} \mathrm{mg} / 1\right)$ internodes in excised Avena shoots incubated in light and dark for $24 \mathrm{hr}$. Averages of six sets of data based on counts in six continuous files of pith or epidermal cells.

\begin{tabular}{|c|c|c|c|c|}
\hline \multirow{2}{*}{ Parameter measured } & \multicolumn{2}{|c|}{ Light } & \multicolumn{2}{|c|}{ Dark } \\
\hline & $-G A_{3}$ & $+G A_{3}$ & $-G A_{3}$ & $+G A_{3}$ \\
\hline & \multicolumn{4}{|c|}{ Internodes $=0.5 \mathrm{~cm}$ at $\mathrm{t}^{\circ}$} \\
\hline Length of internode $\mathrm{cm} \ldots \ldots \ldots \ldots$ & 0.50 & 1.00 & 0.65 & 1.40 \\
\hline No. of epidermal cells $\ldots \ldots \ldots \ldots \ldots \ldots \ldots \ldots$ & 86 & 83 & 110 & 70 \\
\hline 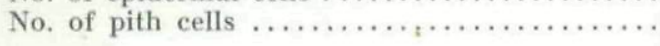 & 80 & 80 & 129 & 91 \\
\hline & \multicolumn{4}{|c|}{ Internode $=1.35 \mathrm{~cm}$ at $\mathrm{t}^{\circ}$} \\
\hline Length of internode $\mathrm{cm}$................... & 1.40 & 2.05 & 2.50 & 3.50 \\
\hline No. of epidermal cells . ................... & 151 & 130 & 216 & 200 \\
\hline No. of pith cells . . . . . . . . . . . . . . . & 144 & 136 & 153 & 140 \\
\hline
\end{tabular}

number in internodes of excised Avena shoots in either light or dark. On the contrary, after $24 \mathrm{hr}$ of incubation of shoots, there is a diminution in number of pith and epidermal cells in $+G A_{3}$, dark incubated shoots. The reason for this is that gibberellic acid actually halts most mitotic activity in the intercalary meristem of internodes after $24 \mathrm{hr}$ of incubation in the dark. In peels taken every $3 \mathrm{hr}$ from time zero, mitoses were observed in the intercalary meristem epidermis up to $18 \mathrm{hr}$ in $+G A_{3}$-incubated internodes, but not after $24 \mathrm{hr}$. By the end of $48 \mathrm{hr}$, cell division activity ceases in the intercalary meristem of internodes in $+G A_{3}$ in the light, and also, in $-G A_{3}$, darkincubated shoots. Cell divisions continue in the intercalary meristem of $-G A_{3}$, light-incubated shoots for as long as $96 \mathrm{hr}$ in excised shoots. A summary of these effects of gibberellic acid on cell number in Avena internodes incubated in light and dark is given below, based on the data in Figure 7 and in Table 3.

Cell division activity persists in the internode up to $96 \mathrm{hr}$. Cell number thus increases continually

$-G A_{3}$ during this period. Light has effect of slowing $\longrightarrow$ down rate of cell division and increasing the period during which mitotic activity occurs in the intercalary meristem.

Light-incubated Avena Shoots

Dark-incubated Avena Shoots
Cell division activity terminates in the internode by $48 \mathrm{hr}$. Duration of cell division in intercalary meristem is thus curtailed by $G A_{3}$.

$-G A_{3}$ Cell division activity persists in the internode up to $48 \mathrm{hr}$. In dark, rate of cell division is faster than in light.

Cell division activity terminates within $24 \mathrm{hr}$ in the intercalary meristem. $+G A_{3}$, here, has effect of drastically reducing duration of mitotic activity in the intercalary meristem in the dark. 
Figure 7. Average lengths of intercalary meristem epidermal cells in Avena internodes, initially $0.5 \mathrm{~cm}$ in length, incubated in $\pm G A_{3}$ at $10^{\circ} \mathrm{mg} / \mathrm{l}$ in light and dark during $96 \mathrm{hr}$ growth period. The following are final lengths of the internode for the different treatments: $-G A_{3}$ light $=0.75 \mathrm{~cm}$; $+G A_{3}$, light $=1.5 \mathrm{~cm} ;-G A_{3}$, dark $=2.25 \mathrm{~cm}$; $+G A_{3}$, dark $=5.0 \mathrm{~cm}$. Arrows indicate time after which no further mitoses were observed in intercalary meristem cells. Maximum standard error $= \pm 14 \mu\left(+G A_{3}\right.$, dark $)$; this is equivalent to 4.67 per cent, which is essentially the same for standard error values for the other points.

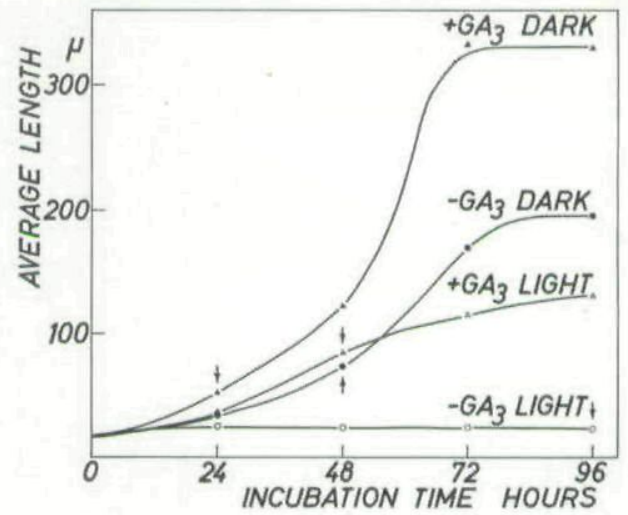

The main point that can be drawn from these findings is that gibberellic acid treatments actually shorten the duration of mitotic activity in the intercalary meristem zone of Avena internodes. Because of this precocious cessation of cell division activity in the intercalary meristem, cell number in $\mathrm{GA}_{3}$ treated internodes is significantly reduced in both pith and epidermis. The promotion of linear growth in Avena internodes by gibberellic acid in light and dark must therefore be ascribed to an increase in cell length.

b. The effect of gibberellic acid on cell elongation. - The acceleratory effect of gibberellic acid on cell elongation in the epidermis of elongating Avena internodes can be observed within the first $24 \mathrm{hr}$ of incubation of excised shoot portions (Figure 7). At $24 \mathrm{hr}$, intercalary meristem epidermal cells in $+G A_{3}$-treated internodes averaged 1.25 times longer in the light and 1.57 times longer in the dark compared with epidermal cells in $-G A_{3}$ internodes. At $96 \mathrm{hr}$, the respective increases were $\times 5.20$ (light) and $\times 1.68$ (dark). The widths of these cells at $96 \mathrm{hr}$ were not significantly different from those of epidermal cells in $-G A_{3}$ internodes: $-\mathrm{GA}_{3}$ (light) $=11.0 \mu ;+G A_{3}$ (light) $=$ $10.1 \mu ;-G A_{3}($ dark $)=12.5 \mu ;+G A_{3}($ dark $)=12.8 \mu$. The increase in rate of cell elongation in the intercalary meristem locus of the internode elicited by gibberellic acid is quite rapid: a maximum of $48 \mu / 24 \mathrm{hr}$ in the light in $+G A_{3}$ (compared with $9 \mu / 24 \mathrm{hr}$ in $-G A_{3}$ ) and a maximum $212 \mu / 24 \mathrm{hr}$ in the dark in $+G A_{3}$ (compared with $106 \mu / 24 \mathrm{hr}$ in $\left.-G A_{3}\right)$. These time-course data on changes in cell length indicate that under the conditions of this experiment (1) $+G A_{3}$ significantly increased the rate of cell elongation, more in dark than in light; (2) duration of cell lengthening was not markedly altered by GAy treatment; and (3) in the light, intercalary meristem epidermal cells did not show much increase in length. The last point is verified by the fact that in $-G A_{3}$, light-incubated shoots, mitotic activity persisted in the intercalary meristem during $96 \mathrm{hr}$ of incubation, as mentioned in the previous section.

The primary acceleration effect of gibberellic acid on lengthening of epidermal cells occurs in basal and middle portions of the internode (Figure 8). In internodes $0.9 \mathrm{~cm}$ in length at time zero, the net increase in length of basal epidermal cells after $48 \mathrm{hr}$ of incubation was 2.1 times greater in $+G A_{3}$ than 


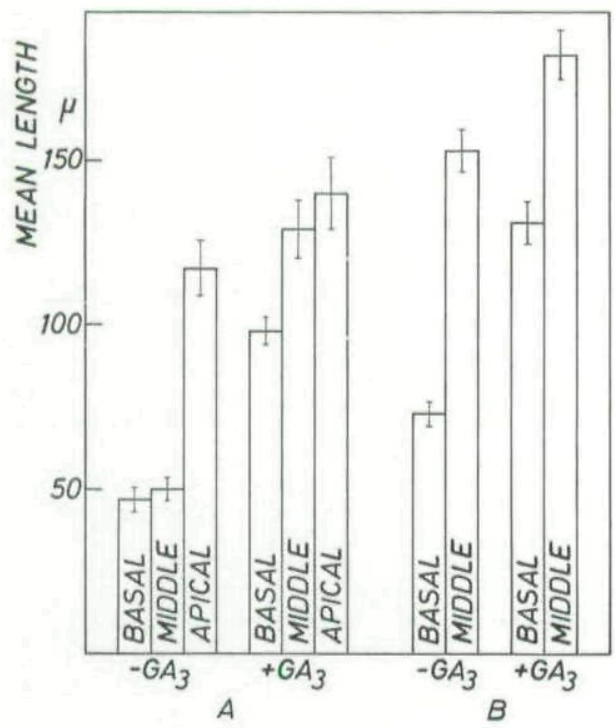

Figure 8. Mean lengths of long epidermal cells at several positions (basal, middle, apical) in Avena internodes at two stages of development $(0.9$ and $1.8 \mathrm{~cm}$ length at $\left.\mathrm{t}^{\circ}\right)$ incubated in the dark at $22.5^{\circ} \mathrm{C}$ in $\pm G A_{3}$ at $10^{2} \mathrm{mg} / \mathrm{l}$ for $48 \mathrm{hr}$. A: internode $=0.9 \mathrm{~cm} ; B$ : internode $=1.8 \mathrm{~cm}$.

in $-G A_{3}$ internodes. In the middle portion, it was 2.78 time greater in $+G A_{3}$ internodes. Even long epidermal cells at the top of the internode are significantly longer as a consequence of $+G A_{3}$ treatments. For older internodes $(1.8 \mathrm{~cm}$ in length at time zero), the greatest increase in cell length elicited by gibberellic acid takes place in the basal portion of the internode in the intercalary meristem locus. Here, long epidermal cells average 1.8 times longer in $+G A_{3}$ than in $-G A_{3}$ internodes. In middle portions, the cells average only 1.2 times longer in $+G A_{3}$-treated internodes. The acceleratory effect of gibberellic acid on cell extension thus diminishes in succeedingly older inter-

Table 4. Lengths and widths of pith cells in continuous cell files in \pm GAs-treated $\left(10^{2} \mathrm{mg} / 1\right)$ internodes in excised Avena shoots incubated in light and dark for 24 hr. Averages of 20 cells in five series of 4 cells continuous to each other at each locus. Maximum standard error $= \pm 14 \mu$.

\begin{tabular}{|c|c|c|c|c|}
\hline \multirow{2}{*}{ Measurement } & \multicolumn{2}{|c|}{ Light } & \multicolumn{2}{|c|}{ Dark } \\
\hline & $-G A_{3}$ & $+G A_{3}$ & $-G A_{3}$ & $+G A_{3}$ \\
\hline & \multicolumn{4}{|c|}{ Length of internode $=0.5 \mathrm{~cm}$ at $\mathrm{t}^{\circ}$} \\
\hline Final length of internode $\mathrm{cm}$. & 0.50 & 1.00 & 0.65 & 1.40 \\
\hline Top of internode $\mu \ldots \ldots \ldots \ldots \ldots \ldots \ldots$ & $97 \times 60$ & $177 \times 60$ & $177 \times 60$ & $237 \times 60$ \\
\hline Middle of internode $\ldots \ldots \ldots \ldots \ldots \ldots \ldots \ldots \ldots$ & $36 \times 45$ & $157 \times 60$ & $31 \times 45$ & $269 \times 60$ \\
\hline Base of internode ........................ & $21 \times 45$ & $56 \times 45$ & $25 \times 45$ & $44 \times 45$ \\
\hline & \multicolumn{4}{|c|}{ Length of internode $=1.35 \mathrm{~cm}$ at $t^{\circ}$} \\
\hline Final length of internode $\mathrm{cm} .$. & 1.40 & 2.05 & 2.50 & 3.50 \\
\hline Top of internode $\mu \ldots \ldots \ldots \ldots \ldots \ldots \ldots$ & $220 \times 60$ & $200 \times 60$ & $175 \times 60$ & $225 \times 60$ \\
\hline Middle of internode $\ldots \ldots \ldots \ldots \ldots \ldots \ldots$ & $211 \times 60$ & $328 \times 60$ & $226 \times 60$ & $414 \times 60$ \\
\hline Base of internode $\ldots \ldots \ldots \ldots \ldots \ldots \ldots \ldots \ldots$ & $34 \times 45$ & $64 \times 53$ & $34 \times 60$ & $70 \times 60$ \\
\hline
\end{tabular}


nodes, as might be predicted from the data in Figure 3, and becomes localized to the base of the internode.

In the pith of Avena internodes, gibberellic acid has an effect on cell elongation (Table 4) similar to that observed in the epidermal system. At $24 \mathrm{hr}$, basal pith cells were 1.83 times longer in $+G A_{3}$, light-incubated internodes and 1.76 times longer in $+G A_{3}$, dark-incubated internodes. In the middle of the internode, where the $\mathrm{GA}_{3}$ effect is even more striking, pith cells in $+G A_{3}$ are four and eight times longer in light and dark, respectively, than in $-G A_{3}$ internodes. In the apical portion of the internode, the effect of gibberellic acid on length of pith cells is of the same order of magnitude as in the intercalary meristem portion. These data show that for short incubation periods, gibberellic acid has its greatest effect on extension of pith cells that lie between the intercalary meristem and the middle of the internode, where cells at the time of treatment are elongating most rapidly.

c. The effect of $\mathrm{GA}_{3}$ on cellular differentiation. - The effects of gibberellic acid on cellular differentiation in the epidermal system of elongating Avena internodes can be observed between 24 and $48 \mathrm{hr}$ after excised Avena shoots are first incubated in $+G A_{3}$ solutions. During this period, the following alterations were observed: (1) Top of the internode - no changes, since cells

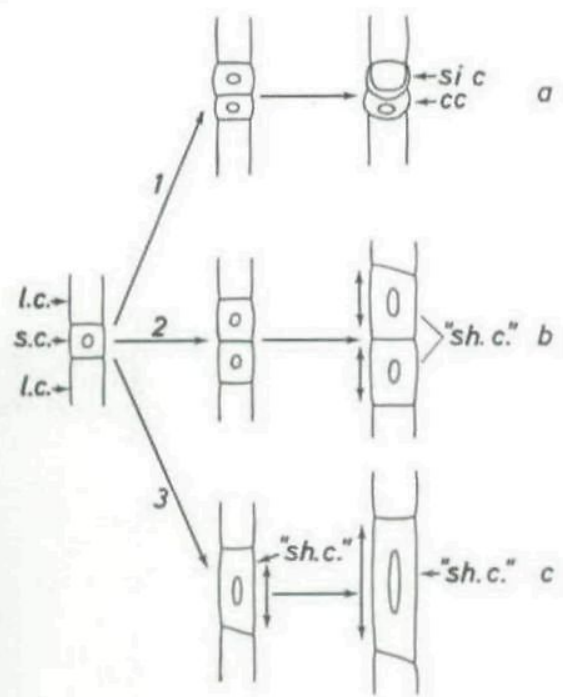

Figure 9.
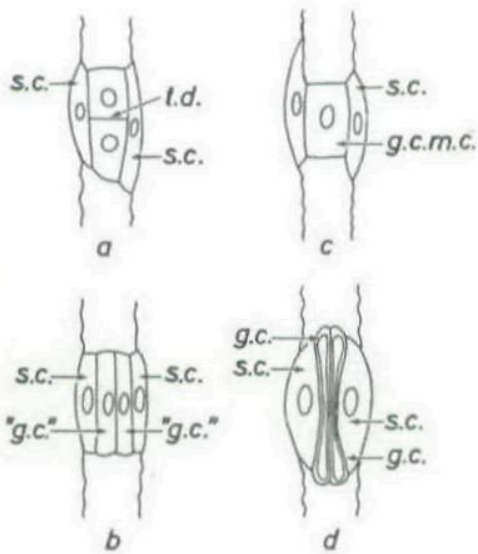

Figure 10.

Figure 9. Pathways of cellular differentiation from short epidermal cell in $-G_{3}$ internode (pathway 1) and in $+G A_{3}$-treated internode in transition zone mentioned in text (pathways 2 and 3 ). $l c=$ long epidermal cell, $s c=$ short epidermal $c e l l, ~ " s h c "=$ abnormally elongated short cell, si $\mathrm{c}=$ silica $c e l l, c c=$ cork cell.

Figure 10. Various stages of arrested cellular differentiation in stomates of + GAs-incubated Avena internodes $(a, b, c)$ compared with fully differentiated stomata (d) from $-G A_{3}$ internode. Details on alterations appear in text. $\mathrm{sc}=$ subsidiary cell, $\mathrm{td}=$ transverse division, "ge" = "guard cell", geme = guard cell mother cell, ge = guard cell. 


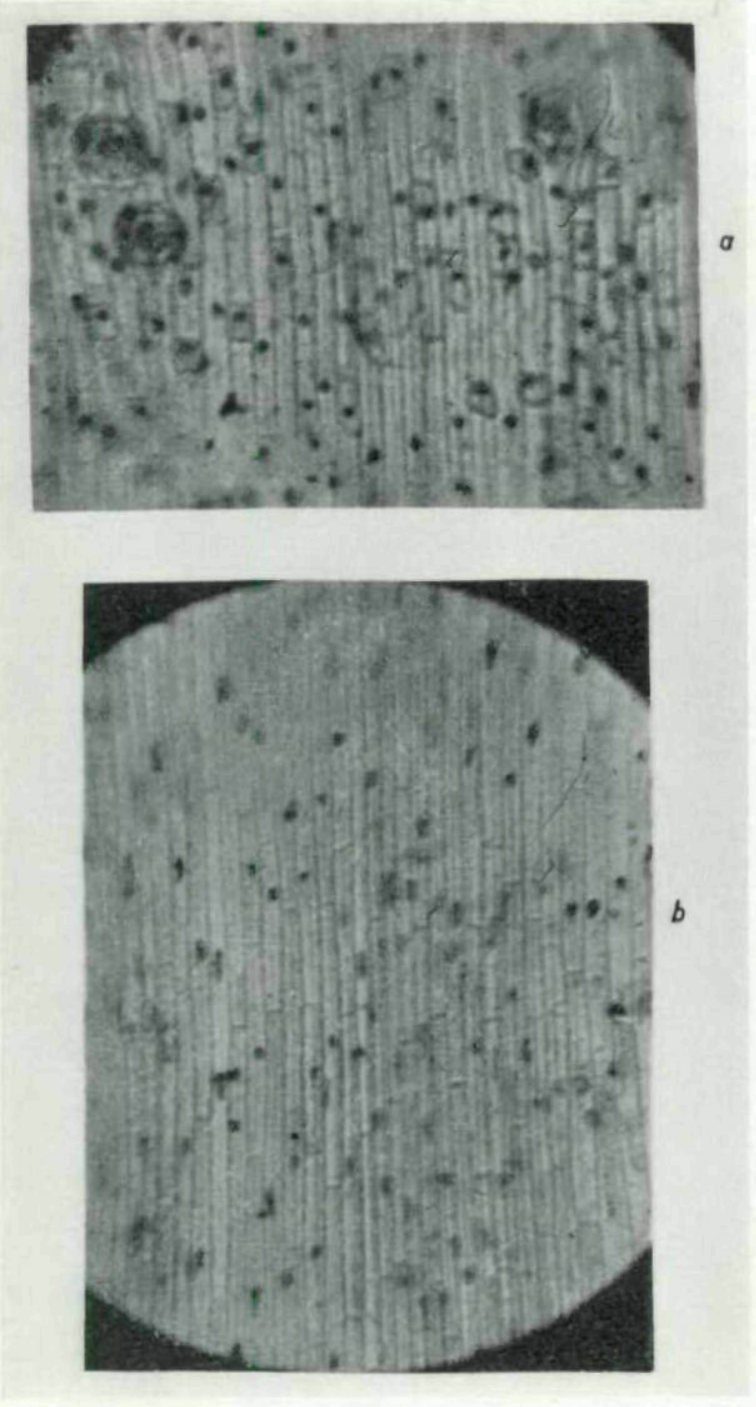

Figure 11. Photomicrographs depicting alterations induced in epidermal cells by $+G A_{3}\left(10^{2} \mathrm{mg} / 1\right)$ in dark-incubated Avena internodes after $48 \mathrm{hr}$ at transition zone $(a)$ and in the intercalary meristem (b). Details are in text. Both $\times 430$.

at this locus have already differentiated at the time shoots are placed in $+G A_{3}$ solution. (2) Middle of the internode to intercalary meristem-progressing basipetally, one observes normally differentiated cells in middle of internode, then a transition zone of cells in various stages of arrested differentiation or altered differentiation, and a zone just above the intercalary meristem having only long epidermal cells. In the transition zone (Figure 11 a), cells were in various stages of final division (stomates and cork cellsilica cell mother cells) and partially completed differentiation at the time exogenous $\mathrm{GA}_{3}$ was added. It is marked by pairs of cells which divide once, 
then elongate instead of developing into pairs of highly differentiated cork and silica cells (pathways 1 and 2, Figure 9), short cells which fail to divide at all and simply elongate (pathways 1 and 3 , Figure 9), "stomates" with undifferentiated guard cells (Figure $10 \mathrm{~b}$, compare with $10 \mathrm{~d}$ ), undivided guard cell mother cells (Figure $10 \mathrm{c}$ ), or guard cells in which final division is transverse rather than longitudinal (Figure 10 a). (3) Base of the internode in intercalary meristem-here, cells by the end of $24 \mathrm{hr}$ cease transverse asymmetric divisions and undergo extensive elongation. By the end of $72 \mathrm{hr}$ in $+G A_{3}$, the entire basal portion of the internode (now ca. 1/3 its total length) is composed of greatly elongated epidermal cells with attenuated and twisted nuclei (Figure $11 \mathrm{~b}$ ). These long cells are similar in appearance to long epidermal cells which normally occur at the extreme base of the internode, below the intercalary meristem, in untreated shoots (Figure 10, Kaufman et al. 1965). The significance of these observations is that exogenous gibberellic acid, supplied in relatively high physiological concentrations $\left(10^{2} \mathrm{mg} / \mathrm{l}\right)$ to excised Avena shoots, (1) has the effect of abolishing nearly all mitotic activity just above and within the intercalary meristem zone of Avena internodes, (2) prevents further differentiation of cells which have proceded along several pathways of differentiation to varying extents, and (3) blocks any cellular differentiation from occurring in intercalary meristem cells within 24 to $48 \mathrm{hr}$ after $\mathrm{GA}_{3}$ is first introduced.

\section{Discussion}

Several salient questions raised by the current investigations on gibberellic acid include the following: (1) What is the physiological basis for differences in growth responses of Avena internodes to gibberellic acid compared with those in other systems? (2) How might one account for the remarkable differences in growth responses of Avena internodes and intercalary meristem cells to IAA and $\mathrm{GA}_{3}$ in light and dark? (3) Why are cell division and cell enlargement responses of intercalary meristem cells in Avena internodes to $\mathrm{GA}_{3}$ so different from those in apical meristems of other plants? (4) What are some possible mechanisms which might explain how exogenous gibberellic acid and IAA promote growth in Avena internodes, and indeed, what roles might endogenous gibberellins and auxins play in regulating intercalary growth in internodes of intact Avena shoots? These four questions will constitute the main focal points in this discussion.

\section{Growth Responses of Avena Internodes to GA $A_{3}$ Compared with Other Systems}

It has been found by many investigators that gibberellic acid accelerates the rate of longitudinal growth in internodes of plants other than grasses (e.g., Brian and Hemming 1958, Brian et al. 1958, Kato 1953, Lockhart 1961, Ng and Audus 1964, Purvis 1960). Roesel and Haber (1963) have recently found that it strongly promotes growth in length in all portions of elongating wheat coleoptiles. With Avena internodes, it is clearly shown here that $\mathrm{GA}_{3}$ accelerates longitudinal growth in both light and dark. There are some rather 
important qualitative and quantitative differences in these growth responses of Avena internodes to exogenously supplied $\mathrm{GA}_{3}$ compared with the responses in Pisum and other shoots, especially when responses in light and dark are compared.

With Avena internodes cultured in light, during stages when there is a wide differential between light and dark growth of internodes $(0$ to $3 \mathrm{~cm})$, the level of growth elicited by $+G A_{3}$ is less than one-half the dark levels of growth (Figures 2,3), and there is an obvious promotion of internodal extension by $+G A_{3}$ in both light and dark. These responses in Avena internodes are thus different from those obtained by Lockhart $(1956,1958,1959,1961)$ with Pisum seedlings in which gibberellic acid (1) can completely overcome red light-induced suppression of longitudinal growth in dwarf peas and (2) cause no significant augmentation in rate of linear growth in dark-grown "Alaska" peas. It is more nearly comparable to responses cited by Nwachuku and Lockhart (1964 for Sinapis alba hypocotyls to $\pm G A_{3}$ in red light and dark, where $+G A_{3}$ light growth is $<-G A_{3}$ dark growth.

Interestingly, in intercalary meristem segments excised from Avena internodes and incubated in the light, gibberellic acid elevates the growth to the same levels which occur in $-G A_{3}$, dark-incubated segments. This is in agreement with Lockhart's findings with dwarf peas. The answer to this apparent paradox lies in the fact that $-G A_{3}$, dark-incubated intercalary meristem segments fail to manifest the striking growth that occurs in internodes in excised Avena shoots at comparable stages of development (internode $=1.5$ $\mathrm{cm}$ length) and incubated under the same conditions (compare Figures 2 and 4). It is possible that some factors, e.g., gibberellin-like substances or auxins, are present in excised shoots above the locus of the internode, not present in intercalary meristem segments (or in extremely low concentrations), which are necessary for linear growth in the internode. The main point here, unequivocally shown by the present investigations, is that gibberellic acid supplied exogenously to light-incubated excised Avena shoots does not completely overcome the inhibitory effects of light on growth of the internodes at early stages of development.

The growth responses of light and dark-incubated Avena internodes in excised shoots to exogenously supplied $\mathrm{GA}_{3}$ are fundamentally the same (Figures 2, 3). Light, compared with dark, has the effect of dampening the growth rate and duration of growth in the internode. $\mathrm{GA}_{3}$ increases the rate of growth without markedly altering duration of growth in either light or dark and causes a net increase in length which is nearly the same in light and dark. In "Alaska" peas grown in dark, $+G A_{3}$ has little effect on longitudinal growth, whereas in light, it augments growth to the dark level (Lockhart 1956); with dwarf peas, $+G A_{3}$ gives a positive growth increase which is nearly the same in light and dark. Thus, growth responses of Avena internodes to $\mathrm{GA}_{3}$ more closely resemble the responses of internodes in the dwarf pea, except for the failure of $\mathrm{GA}_{3}$ to elevate growth in the light to the dark level in Avena internodes. Unlike peas ( $\mathrm{Ng}$ and Audus 1964, Brian et al. 1958), Avena internodes apparently have no requirement for exogenous auxin for promotion of growth in light by gibberellic acid. One cannot escape the conclusion that with Avena internodes, there is no interaction between light and $\mathrm{GA}_{3}$, but rather, $+G A_{3}$ light or dark-grown internodes 
grow in basically the same manner and behave physiologically different from $-G A_{3}$ internodes growing in light or dark. One must conclude from this that the light controls of intercalary growth and the gibberellin controls of intercalary growth in Avena internodes are operating at different sites and via different mechanisms.

\section{Comparison of Growth Responses of Avena Internodes and Intercalary Meristem Cells To IAA and $\mathrm{GA}_{3}$}

The current and previous investigations demonstrate that gibberellic acid and indole-3-acetic acid have remarkably different effects on intercalary growth in Avena internodes. It was found that IAA strongly promotes longitudinal growth in the internode in the light, and conversely, in the dark, it represses their growth to an equal extent (Kaufman 1965). IAA also substantially augments transverse growth of the internode, particularly in the light. Gibberellic acid, on the other hand, at comparable concentrations, accelerates longitudinal growth of Avena internodes in both light and dark while having no significant effect on transverse growth. Both IAA and GA9 cause significant increases in internode dry weight at several concentrations. In essence, then, the promotion of intercalary growth in Avena internodes by IAA is strongly light dependent, whereas the $\mathrm{GA}_{3}$ response is neither light nor dark dependent even though the promotion of growth by $\mathrm{GA}_{3}$ is more strongly expressed in dark than in light. This evidence from the work on Avena internodes leads one to the conclusion that $\mathrm{GA}_{3}$ and IAA have basically different mechanisms of action as proposed by many other investigators. This idea is even more clearly seen in a comparison of response of intercalary meristem cells of Avena internodes to IAA and $\mathrm{GA}_{3}$.

Primary differences in the growth responses of intercalary meristem epidermal cells in Avena internodes to IAA and $\mathrm{GA}_{3}$ are depicted in Figure 12.

Figure 12. Comparison of patterns of cell expansion and first stages of cellular differentiation in untreated intercalary meristem epidermal cells (pathway 1) with those in internodes incubated in $I A A$ and $G A_{3}(10 \mathrm{mg} / 1)$ in pathways 2 and 3 , respectively.

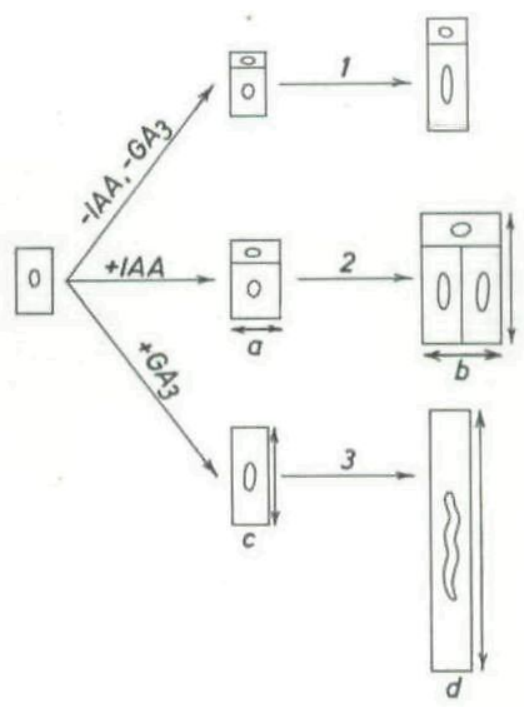


IAA (pathway 2) has the effect of greatly augmenting transverse growth of the cell, while at the same time, promoting its growth longitudinally (Figure 12 a). In such a cell, the first stage of differentiation, namely a transverse asymmetric division, takes place as in untreated internodes (pathway 1). The products of this division (Figure $12 \mathrm{~b}$ ) enlarge in both directions with the long cell member frequently dividing longitudinally to form a pair of long cells, which also expand laterally and longitudinally in response to IAA. $\mathrm{GA}_{3}$ (pathway 3), in contrast, has the effect of blocking asymmetric divisions in intercalary meristem cells, and thus, effectively halting the first stage of cellular differentiation in the intercalary meristem. The intercalary meristem cells simply elongate to lengths greatly exceeding those in untreated cells (compare $c$ and $d$ with pathway 1 in Figure 12) with no significant alteration in amount of transverse growth. IAA thus plays a role in transverse and longitudinal growth of intercalary meristem cells without altering earliest stages in their cellular differentiation; these growth reactions of intercalary meristem cells to IAA are strongly light dependent. $\mathrm{GA}_{3}$ acts primarily on cell lengthening while blocking early differentiation in intercalary meristem cells, effects which are most strongly expressed in the dark. Such remarkable differences in responses of intercalary meristem cells in Avena internodes to IAA and $\mathrm{GA}_{3}$ certainly suggest fundamental differences in their mechanisms of action at the cellular level, which must reflect rather fundamental differences in their modes of action at the biochemical level. These will be alluded to in section 4 .

\section{Effect of $\mathrm{GA}_{3}$ on Cell Division and Cell Enlargement}

It is now well-established that exogenously supplied gibberellic acid may (1) increase cell size (Allsopp 1962, Burström 1960, Bradley and Crane 1962, Humphries and Wheeler 1960, Kato 1965), (2) increase cell number (Bernier et al. 1964, Greulach and Haesloop 1958, Sachs et al. $1959 a, b$ ), (3) increase both cell number and cell size (Guttridge and Thompson 1963, Humphries and Wheeler 1960), and (4) decrease cell number (Burström 1960, Odhnoff 1963) or cell size (Burström 1960). Such diverse effects of gibberellic acid on cell multiplication and cell enlargement are obviously dependent on the part of the plant investigated and the particular environmental regime employed.

In contrast with the effects of gibberellic acid on cell division in apical meristems of certain rosette plants (see 2 above), it was found in the present studies that gibberellic acid drastically shortens the duration of mitotic activity in the intercalary meristem of Avena internodes with no evidence that it actually increases rate of cell division (Table 3) in intercalary meristem cells during short incubation periods. Within $24 \mathrm{hr}$ in dark-incubated Avena shoots, cell division ceases in the intercalary meristem of $+G A_{3}$ internodes; in the light, it is halted within $48 \mathrm{hr}$. Concommitantly, $\mathrm{GA}_{3}$ accelerates rate of cell elongation in the intercalary meristem and in elongating cells above the intercalary meristem, the rates of acceleration being greater in dark than in light. It is therefore clear that gibberellic acid shortens the duration of cell multiplication in the intercalary meristem of Avena internodes and accelerates the rate of cell elongation in pith and epidermal 
systems, particularly in the dark. Similar effects of gibberellic acid on cell division are also cited by Burström (1960) for wheat roots. In view of these results, one must conclude that cells of the intercalary meristem in Avena internodes, representing components of a residual meristem derived originally from the apical meristem, are not physiologically comparable to cells in the apical meristem itself. The effects of $\mathrm{GA}_{3}$ on cell multiplication in the two systems are not the same; in the apical meristem, it primarily affects the rate of cell division, and in the internodal intercalary meristem of Avena, the effect is primarily on duration of cell multiplication. However, it is essential to stress that the most important effect of $\mathrm{GA}_{3}$ in Avena internodes is on the process of cell lengthening as so clearly shown in Figures 7 and 12.

\section{Possible Mechanisms of Action of $\mathrm{GA}_{3}$ and IAA in Growth of Avena Internodes}

It has been shown by Kuraishi and Muir $(1964 a, b)$ and others that exogenous gibberellic acid increases the amount of diffusible auxin in various plant tissues and organs. They also showed that this effect of GA was probably one of promoted biosynthesis of diffusible auxin rather than a decrease in rate of enzymatic destruction of auxin by IAA oxidase. If $\mathrm{GA}_{3}$ causes a similar increase in amount of diffusible auxin in Avena internodes, it could be argued that some of this increase is partially negated by destruction of IAA by light. This would then offer a plausible explanation for the failure of $+G A_{3}$ to overcome completely the suppression of linear growth of the internode by light. The critical question that must be answered is whether an increase in diffusible auxin in the internode is causally related to the acceleration in rate of linear growth elicited by exogenously supplied gibberellic acid. It is certainly possible that $\mathrm{GA}_{3}$ might also act indirectly in the process of internodal extension by increasing amylase activity, as in barley endosperm (Paleg 1960), and hence increase substrate available for cell wall synthesis. Coupled with this, $\mathrm{GA}_{3}$ could also increase cell wall plasticity (Lockhart 1961) or alter the elastic properties of the cell wall in a way that differs from the effects of IAA (Yoda and Ashida 1960).

Finally, it would seem appropriate here to offer several speculations on possible roles that native gibberellins might play in the linear extension of internodes of the Avena plant. Gibberellin-like substances, or their precursors, could be produced in the inflorescence, as already shown by Nichols and May (1964) for barley inflorescences, and the last leaf above the internode (cf. Figure 1 in Kaufman 1965). From these sites, they could move basipetally to elongating internodes, where they would play a decisive role, together with native auxins and inhibitors, in linear growth. In Avena, the primary site of action would be the intercalary meristem. Lockhart (1957, 1964) has presented rather similar views on the possible roles of native gibberellins in extension of pea internodes. Since the rates of longitudinal growth in internodes of excised Avena shoots are never as great as in intact shoots (Kaufman et al. 1965), one cannot exclude the possibility that some gibberellin-like substances might also be derived from the root system and portions of the shoot below the internode, especially in light of recent evidence that native gibberellins are present in considerable quantities in 
bleeding sap derived from decapitated root systems (Phillips and Jones 1964, Carr et al. 1964).

The writer favors the view that in the Avena internode system, native auxins and gibberellins, together with other factors (as sugars, native inhibitors) must act in a balanced system to control rates and duration of cell division and cell enlargement. From the studies with exogenously supplied IAA and $\mathrm{GA}_{3}$, it would appear that auxin might act primarily in the light and would exert some control over the orientation of the plane of cell division and both transverse and longitudinal components of cell enlargement. Gibberellin-like substances, in contrast, might act primarily in the dark on longitudinal component of cell enlargement and exert a braking action on the duration of cell multiplication in the intercalary meristem. Testing of these ideas must await further investigations on roles that native auxins and gibberellins play in cell division, cell enlargement, and cellular differentiation during intercalary growth in Avena internodes.

\section{Summary}

1. The acceleration by gibberellic acid in rate of extension of next to last internodes in excised Avena shoots occurs in both light and dark. The amount of promotion of growth by gibberellic acid in light is not sufficient to overcome completely the inhibitory effects of light on linear extension during early stages of development of the internode (0 to $3 \mathrm{~cm}$ length).

2. The linear growth of internodes in excised Avena shoots is strongly promoted by gibberellic acid over a fairly wide concentration range $\left(10^{-1}\right.$ to $10^{2} \mathrm{mg} / \mathrm{l}$ ) in the dark. This promotion is primarily due to an acceleration in rate of linear extension of the internode.

3. The primary locus of response of Avena internodes to gibberellic acid is the intercalary meristem zone. This corresponds to the same site which is most active in linear extension of dark-incubated untreated internodes.

4. Gibberellic acid precociously halts cell multiplication (transverse asymmetric divisions) in the intercalary meristem of Avena internodes, resulting in a diminution in cell number in both pith and epidermal systems. Concommitantly, it greatly augments the rate of cell elongation in pith and epidermal cells in the intercalary meristem and in elongating cells above it, particularly in the dark. The duration of cell elongation is not appreciably affected by gibberellic acid in the dark.

5. Cellular differentiation in epidermal idioblasts (cork and silica cells and stomates) is halted in Avena internodes by gibberellic acid, resulting in formation of several anomalous kinds of epidermal cells above the intercalary meristem and extremely elongate epidermal cells in the locus of the intercalary meristem.

The author expresses his appreciation to Professor Hans Burström for stimulating discussions, constructive criticism of the manuscript, and for use of facilities at the Institute of Plant Physiology, Lund University, Lund, Sweden while the author was on sabbatical leave.

This investigation was supported under auspicies of NSF GB 2688.

Physiol. Plant., 18, 1965 


\section{References}

Allsopp, A.: The effects of gibberellic acid on morphogenesis in Marsilea drummondii A. Br. - Phytomorphol, 12: 1-10. 1962.

Bernier, G., Bronchart, R. \& Jacquard, A.: Action of gibberellic acid on the mitotic activity of the different zones of the shoot apex of Rudbeckia bicolor and Perilla nankinensis. - Planta 61: 236-244. 1964.

Bradley, M. V. \& Crane, J. C.: Cell division and enlargement in mesocarp parenchyma of gibberellin-induced parthenocarpic peaches. - Bot. Gaz. 123: 243-246. 1962.

Brian, P. W. \& Hemming, H. G.: Complementary action of gibberellic acid and auxins in pea internode extension. - Ann. Bot. N.S. 22: 1-17. 1958.

- - \& Lowe, D.: Effect of gibberellic acid on rate of extension and maturation of pea internodes. - Ibid. 22: 539-542. 1958.

Burström, H.: Influence of iron and gibberellic acid on the light sensitivity of roots. Physiol. Plant. 13: 597-615. 1960.

Carr, D. J., Reid, D. M. \& Skene, K. G. M.: The supply of gibberellins from the root to the shoot. - Planta 63: 382-392. 1964.

Greulach, V. A. \& Haesloop, J. G.: The influence of gibberellie acid on cell division and cell elongation in Phaseolus vulgaris. - Amer. J. Bot. 45: 566-570. 1958.

Guttridge, C. G. \& Thompson, P. A.: The effect of daylength and gibberellic acid on cell length and number in strawberry petioles. - Physiol. Plant. 16:604-614. 1963.

Humphries, E. C. \& Wheeler, A. W.: The effects of kinetin, gibberellic acid, and light on expansion and cell division in leaf disks of dwarf bean (Phaseolus vulgaris), - J. Exp. Bot. 11: 81-85. 1960.

Kato, J.: Responses of plant cells to gibberellin. - Bot. Gaz. 117: 16-24. 1955.

Kaufman, P. B.: The effects of growth substances on intercalary growth and cellular differentiation in developing internodes of Avena sativa. I. The effects of indole-3-acetic acid. - Physiol. Plant. 18: 424-443. 1965.

— \& Cassell, S. J.: Striking features in the development of internodal epidermis of the oat plant (Avena sativa). - Mich. Botanist 2: 115-121. 1963.

- $-\&$ Adams, P. A.: On the nature of intercalary growth and cellular differentiation in internodes of Avena sativa. - Bot. Gaz. 126:1-13. 1965.

- Katz, J. M. \& Yoder, M. E.: Growth responses of Avena stem segments to various sugars. - Nature 196: 1332-1333. 1962.

Kuraishi, S. \& Muir, R. M.: The relationship of gibberellin and auxin in plant growth. Plant Cell Physiol. 5: 61-69. $1964 a$.

- The mechanism of gibberellin action in the dwarf pea. - Ibid. 5:259-271. 1964 $b$.

Lockhart, J. A.: Reversal of the light inhibition of pea stem growth by the gibberellins. Proc. Natl. Acad. Sci. (Wash.) 42: 841-848. 1956.

- Studies of the organ of production of the natural gibberellin factor in higher plants. Plant Physiol. 32: 204-207. 1957.

- The response of various species of higher plants to light and gibberellic acid. Physiol. Plant. 11: 478-486. 1958.

- Studies on the mechanism of stem growth inhibition by visible radiation. - Plant Physiol. 34: 457-460. 1959.

- Interactions between gibberellin and various environmental factors on stem growth. Amer. J. Bot. 48: 516-525. 1961.

- The hormonal mechanism of growth inhibition by visible radiation. - In Plant Growth Regulation, 4th Intern. Conf., pp. 543-557. Iowa State Univ. Press, Ames, Iowa. 1961.

- Physiological studies on light sensitive stem growth. - Planta 62:97-115. 1964.

Ng, E. K. \& Audus, L. J.: Growth regulator interactions in the growth of the shoot system of Avena sativa seedlings. I. The growth of the first internode. - J. Exp. Bot. 15: 67-95. 1964.

Nicholls, P. B. \& May, L. H.: Studies on the growth of the barley apex. II. On the initiation of internodal elongation in the inflorescence, - Austr. J. Biol. Sci. 17:619-630. 1964.

Nwachuku, I. C. \& Lockhart, J. A.: Hypocotyl elongation in mustard and mung bean seedlings as influenced by light, gibberellin, and chlorocholine chloride. - Physiol. Plant. 17: 725-736. 1964.

Odhnoff, C.: The effect of gibberellin and phenylboric acid on xylem differentiation and epidermal cell elongation in bean roots. - Ibid. 16:474-483. 1963. 
Paleg, L. G.: Physiological effects of gibberellic acid. I. On carbohydrate metabolism and amylase activity of barley endosperm. - Plant Physiol. 35: 293-299. 1960.

Phillips, I. D. J. \& Jones, R. L.: Gibberellin-like activity in bleeding-sap of root systems of Helianthus annuus detected by a new dwarf pea epicotyl assay and other methods. — Planta 63: 269-278. 1964.

Purvis, O. N.: Effect of gibberellin on flower initiation and stem extension in Petkus winter rye. - Nature 185: 479. 1960.

Roesel, H. A. \& Haber, A. H.: Studies on the effects of light on growth pattern and of gibberellin sensitivity in relation to age, growth rate, and illumination in intact wheat coleoptiles. - Plant Physiol. 38: 523-532. 1963.

Sachs, R. M. Bretz, C. F. \& Lang, A.: Shoot histogenesis: the early effects of gibberellin upon stem elongation in two rosette plants. - Amer. J. Bot. 46:376-384. $1959 a$.

- - Cell division and gibberellic acid. - Exp. Cell Res. 18: 230-244. $1959 \mathrm{~b}$.

Yoda, S. \& Ashida, J.: Effects of gibberellin and auxin on the extensibility of the pea stem. - Plant Cell Physiol. 1: 99-105. 1960. 
This document is a scanned copy of a printed document. No warranty is given about the accuracy of the copy. Users should refer to the original published version of the material. 